\title{
Penerapan Metode Multidimensional Scaling dalam Pemetaan Sarana Kesehatan di Jawa Barat
}

\author{
Julita Nahar \\ Program Studi Matematika, Fakultas MIPA, Universitas Padjadjaran \\ Jl. Raya Bandung Sumedang KM 21 Jatinangor Sumedang 45363 \\ Email: julitanahar@yahoo.co.id
}

\begin{abstract}
ABSTRAK
Upaya kesehatan dapat diwujudkan dalam suatu pelayanan kesehatan atau sarana kesehatan. Kesehatan sangat berarti untuk pembangunan kesejahteraan masyarakat Indonesia. Pelayanan kesehatan yang baik akan menciptakan masyarakat yang sehat diseluruh kawasan baik dipedesaan maupun perkotaan. Penelitian ini ditujukan untuk memetakan sarana kesehatan yang ada di kota-kota di Jawa Barat. Hasil analisis yang dilakukan dengan menggunakan analisis Multidimensional Scaling memperlihatkan bagaimana pengelompokan kota-kota di Jawa Barat berdasarkan sarana kesehatan yang dimilikinya, Dari hasil pemetaan terdapat tiga kelompok kota yang memiliki kemiripan antar anggotanya namun berbeda dengan kelompok lainnya. Tiap kelompok yang terbentuk memiliki kemiripan karakteristik dari jumlah fasilitas sarana kesehatan..
\end{abstract}

Kata Kunci : Multidimensional Scaling, pemetaan, sarana kesehatan

\begin{abstract}
Health efforts can be realized in a health care or health care facilities. Health is very significant for the development of the welfare of Indonesian society. Good health care will create a healthy society across the region both rural and urban areas. This study aimed to map existing health facilities in cities in West Java. The results of the analysis conducted by using Multidimensional Scaling analysis shows how grouping the cities in West Java by its health facilities. From the mapping of the cities there are three groups that have similarities among its members but different from the other groups. Each group formed have similar characteristics of a number of health care facilities.
\end{abstract}

Keywords: Multidimensional Scaling, mapping, health facilities

\section{Pendahuluan}

Upaya kesehatan dapat diwujudkan dalam suatu wadah pelayanan kesehatan atau sarana kesehatan. Berdasarkan UU No. 23 tahun 1992 tentang Kesehatan, sarana kesehatan adalah tempat yang digunakan untuk menyelenggarakan upaya kesehatan. Kesehatan sangat berarti untuk pembangunan kesejahteraan masyarakat Indonesia dan sebagai modal bagi pelaksanaan pembangunan nasional yang pada hakikatnya adalah pembangunan manusia Indonesia seutuhnya dan pembangunan seluruh masyarakat Indonesia. Kesehatan sebagai salah satu unsur kesejahteraan umum harus diwujudkan sesuai dengan cita-cita bangsa Indonesia sebagaimana dimaksud dalam Pembukaan Undang-Undang Dasar 1945 melalui pembangunan nasional yang berkesinambungan berdasarkan Pancasila dan Undang-Undang Dasar 1945.

Dengan pelayanan kesehatan yang baik akan menciptakan masyarakat yang sehat diseluruh kawasan baik dipedesaan maupun perkotaan. Sebagai tolok ukur dalam bidang 
kesehatan dapat dilihat dari peningkatan ekonomi masyarakat karena kesehatan merupakan unsur yang penting dalam meningkatkan produktifitas masyarakat.

Dalam penelitian ini, penulis melakukan pemetaan sarana kesehatan berdasarkan jarak pada peta konfigurasi yang ada di kota-kota di Jawa Barat, sehingga dari hasil analisis yang dilakukan dapat terlihat bagaimana pengelompokan kota-kota di Jawa Barat berdasarkan sarana kesehatan yang dimilikinya, yang mana pemetaan tersebut dilakukan dengan menggunakan analisis Multidimensional Scaling.

\section{Metode Penelitian}

\subsection{Analisis Multidimensional Scalling (MDS)}

Analisis Multidimensional Scalling (MDS) merupakan salah satu teknik peubah ganda yang dapat digunakan untuk menentukan posisi suatu obyek lainnya berdasarkan penilaian kemiripannya, juga untuk mengetahui hubungan interdepensi atau saling ketergantungan antar variabel atau data (Johnson, 1992). Hubungan ini tidak diketahui melalui reduksi ataupun pengelompokan variabel, melainkan dengan membandingkan variabel yang ada pada setiap obyek yang bersangkutan dengan menggunakan perceptual map. MDS berhubungan dengan pembuatan peta untuk menggambarkan posisi sebuah obyek dengan obyek lainnya berdasarkan kemiripan obyek-obyek tersebut. MDS juga merupakan teknik yang bisa membantu peneliti untuk mengenali (mengidentifikasi) dimensi kunci yang mendasari evaluasi objek dari responden (pelanggan).

Menurut Hair dkk (1998), penskalaan dimensi ganda mengacu pada sebuah metode yang membantu mengidentifikasi ukuran pokok yang mendasari penilaian responden terhadap sebuah obyek, sebagai contoh penskalaan dimensi ganda seringkali digunakan di bidang pemasaran untuk mengidentifikasi ukuran pokok yang mendasari penilaian konsumen terhadap sebuah produk atau terhadap pelayanan. Penskalaan dimensi ganda juga dikenal sebagai peta persepsi (perceptual map), yaitu metode yang mengambarkan atau memetakan kesan relatif yang dirasakan terhadap sejumlah obyek (perusahaan, produk atau lainnya yang berhubungan dengan persepsi).

\section{$2.2 \quad J e n i s-j e n i s$ Multidimensional Scalling (MDS)}

Menurut A. Walundungo (2014), untuk melakukan analisis data dengan Multidimensional Scalling (MDS) digunakan nilai-nilai yang menggambarkan tingkat kemiripan atau tingkat ketakmiripan antar objek yang disebut proximity yang terbagi atas similarity (kemiripan) dan dissimilarity (ketakmiripan). Berdasarkan tipe data tersebut, MDS dibagi menjadi dua yaitu multidimensional scaling metrik dan multidimensional scaling nonmetrik.

\subsubsection{Multidimensional Scaling Metrik}

Data jarak yang digunakan dalam penskalaan adalah data interval atau rasio. Dalam Multidimensional Scaling metrik tidak dipermasalahkan apakah data input ini merupakan jarak yang sebenarnya atau tidak, prosedur ini hanya menyusun bentuk geometri dari titiktitik objek yang diupayakan sedekat mungkin dengan input jarak yang diberikan.

\subsubsection{Multidimensional Scaling Non-Metrik}

Data jarak yang digunakan dalam transformasi monoton (sama) ke data yang sebenarnya sehingga dapat dilakukan operasi aritmatika terhadap nilai ketidaksamaannya, untuk menyesuaikan jarak dengan nilai urutan ketidaksamaannya. Transformasi monoton akan memelihara urutan nilai ketidaksamaannya sehingga jarak antara objek yang tidak sesuai dengan urutan nilai ketidaksamaan dirubah sedemikian rupa sehingga akan tetap memenuhi urutan nilai ketidaksamaan tersebut dan mendekati jarak awalnya. 


\subsection{Prosedur Analisis Multidimensional Scaling}

Analisis Multidimensional scaling adalah untuk memetakan persepsi (perceptual map) secara visual dalam peta multidimensi. Dari Ginanjar (2008) menerangkan beberapa tahapan analisis dalam melakukan analisis Multidimensional Scaling adalah :

1. Menghitung matriks jarak dengan menggunakan jarak Euclidean. Kedekatan antar objek pada perceptual map dapat dihitung dengan menggunakan jarak Euclidean antara objek pertama sampai dengan objek ke-j dengan rumus sebagai berikut :

$$
d_{i j}=\sqrt{\sum_{k=1}^{p}\left(x_{i h}-x_{j h}\right)^{2}}
$$

dimana :

$d_{i j}=$ jarak antar objek ke-i dan objek ke-j

$x_{i j h}=$ hasil pengukuran objek ke-i pada peubah $\mathrm{h}$

$x_{j h}=$ hasil pengukuran objek ke-j pada peubah $\mathrm{h}$

2. Mencari nilai eigen value dan eigen vector dengan rumusan sebagai berikut :

$$
\operatorname{det}(B-\lambda I) \text { dan } \operatorname{det}(B-\lambda I) X
$$

Dimana menghitung matriks B dengan elemen-elemen

$$
b_{i j}=-\frac{1}{2}\left(d_{i j}^{2}-d_{i .}^{2}-d_{. j}^{2}+d_{. .}^{2}\right)
$$

dimana :

$$
\begin{aligned}
& d_{i .}^{2}=\frac{1}{n} \sum_{i} d_{i j}^{2} \\
& d_{. j}^{2}=\frac{1}{n} \sum_{i} d_{i j}^{2} \\
& d_{. .}^{2}=\frac{1}{n^{2}} \sum_{i i} d_{i j}^{2}
\end{aligned}
$$

3. Membentuk koordinat objek berdasarkan vektor eigen $X=\left[\begin{array}{ll}x_{1} & x_{2}\end{array}\right]$, kemudian selanjutnya menghitung $\hat{D}$ yang merupakan jarak Uclidean dari koordinat terbentuk.

4. Menghitung nilai stress dengan rumus sebagai berikut :

$$
S=\left(\frac{\sum_{i=j}^{n}\left(d_{i j}-\hat{d}_{i j}\right)^{2}}{\sum_{i=j}^{n} d_{i j}^{2}}\right)
$$

Semakin kecil nilai STRESS menunjukkan bahwa hubungan monoton yang terbentuk antara ketidaksamaan dengan disparities semakin baik (didapat kesesuaian) dan kriteria peta persepsi (perceptual map) yang terbentuk semakin sempurna.

\subsection{Data Penelitian}

Data penelitian ini adalah data sekunder yang diambil dari http://jabar.bps.go.id dengan bukunya yang berjudul Jawa Barat dalam Angka 2014. Data yang diambil adalah data jumlah sarana kesehatan di semua kota di Jawa Barat pada tahun 2013. Sarana kesehatan terdiri dari Rumah Sakit Umum (RSU), Rumah Sakit Ibu Anak/Bersalin (RSA), Puskesmas, Posyandu, Balai Pengobatan dan Apotek. 


\subsection{Tahapan Analisis}

Dibawah ini adalah alur diagram dalam tahapan analisis multidimensional scaling :

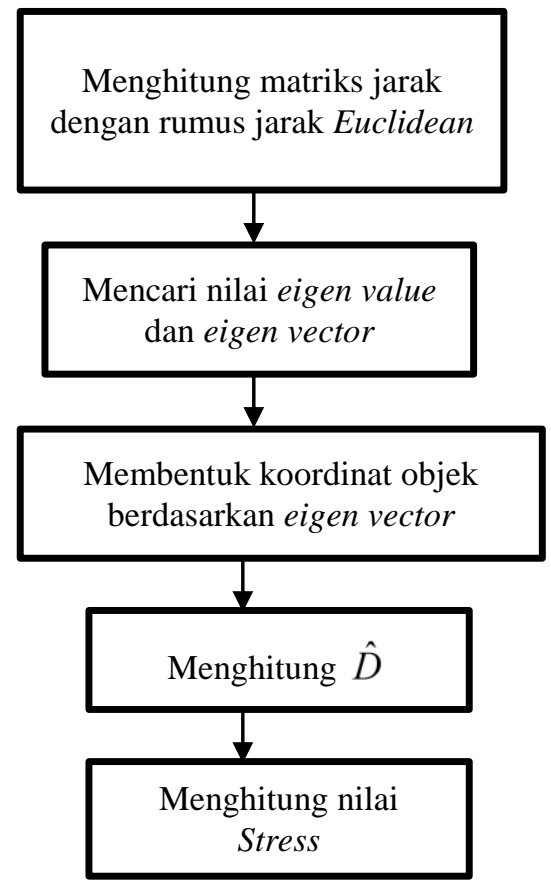

Gambar 1. Tahapan Analisis Multidimensional Scaling (MDS)

\section{Hasil dan Pembahasan}

\subsection{Menghitung Matriks Jarak Euclidien}

Matriks jarak euclidien pada analisis MDS dihitung dengan menggunakan rumus yang telah dijabarkan sebelumnya, sehingga didapatkan matriks Jarak Euclidean dengan bantuan software SPSS adalah sebagai berikut:

\begin{tabular}{l|lllllllll|}
\multicolumn{1}{l}{} & 1 & 2 & 3 & 4 & 5 & 6 & 7 & 8 & 9 \\
1 & 0 & & & & & & & & \\
2 & 261,105 & 0 & & & & & & & \\
3 & 779,003 & 940,952 & 0 & & & & & \\
4 & 210,554 & 56,471 & 899,553 & 0 & & & & \\
5 & 348,948 & 563,584 & 453,078 & 512,857 & 0 & & & & \\
6 & 199,805 & 447,616 & 624,566 & 394,187 & 173,675 & 0 & & & \\
7 & 173,819 & 91,657 & 871,811 & 54,882 & 481,51 & 360,972 & 0 & & \\
8 & 159,809 & 102,699 & 867,435 & 51,245 & 470,362 & 346,233 & 33,971 & 0 & \\
9 & 273,728 & 31 & 945,735 & 80,062 & 574,105 & 460,651 & 100,578 & 119,791 & 0
\end{tabular}

\subsection{Hasil Grafik Pemetaan}

Berdasarkan grafik koordinat stimulus di atas dapat dihasilkan output grafik pemetaan untuk pemetaan sarana kesehatan di seluruh kota di Jawa Barat adalah sebagai berikut : 




Gambar 2. Grafik Pemetaan Kota di Jawa Barat Berdasarkan Jumlah Sarana Kesehatan

Gambar 2 di atas menunjukan posisi dari 9 Kota di Jawa Barat berdasarkan jumlah sarana kesehatan yang ada pada kota-kota tersebut yaitu Rumah Sakit Umum (RSU), Rumah Sakit Ibu Anak/Bersalin (RSA), Puskesmas, Posyandu, Balai Pengobatan dan Apotek pada tahun 2013.

Grafik yang disajikan dalam gambar 2 dimensi (sumbu X dan sumbu Y). Informasi yang diperoleh dari grafik di atas adalah jika kita mengambil titik $(0,0)$ sebagai koordinat pusat dan ditarik garis lurus, sehingga grafik terbagi menjadi 4 kuadran, maka :

Kuadran I (kiri atas) : Terdiri dari 1 Kota di Jawa Barat yaitu Kota Bandung. Kota Bandung dipandang memiliki perbedaan dari karakteristik dalam jumlah fasilitas sarana kesehatan karena Kota Bandung memiliki posisi yang terletak berpisah dengan kota-kota lainnya.

Kuadran II (kanan atas) : Terdiri dari 5 Kota di Jawa Barat yaitu Kota Tasikmalaya, Kota Cimahi, dan Kota Banjar, Kota Cirebon, dan Kota Sukabumi. Kelima kota tersebut dipandang memiliki kemiripian dari karakteristik dalam jumlah fasilitas sarana kesehatan karena terletak pada kuadran yang sama.

Kuadran III (kanan bawah) : Terdiri dari 1 Kota di Jawa Barat yaitu Kota Bogor. Kota Bogor dipandang memiliki perbedaan dari karakteristik dalam jumlah fasilitas sarana kesehatan karena Kota Bogor memiliki posisi yang terletak berpisah dengan kota-kota lainnya.

Kuadran IV (kiri bawah) : Terdiri dari 2 Kota di Jawa Barat yaitu Kota Bekasi, dan Kota Depok. Kedua kota tersebut dipandang memiliki kemiripian dari karakteristik dalam jumlah fasilitas sarana kesehatan karena terletak pada kuadran yang sama.

Apabila dilihat dari plot secara keseluruhan terdapat tiga kelompok kota yang memiliki kemiripan antar anggotanya namun berbeda dengan kelompok lainnya. Ketiga kelompok tersebut adalah :

- Kelompok 1 : Kota Banjar, Kota Sukabumi, Kota Tasikmalaya, Kota Cirebon, dan Kota Cimahi

- Kelompok 2 : Kota Bandung

- Kelompok 3 : Kota Bekasi, Kota Bogor, dan Kota Depok

Dari kelompok yang terbentuk dapat dikatakan bahwa pada kelompok satu memiliki jumlah fasilitas kesehatan yang baik, sedangkan dari kelompok 2 dapat dikatakan memiliki jumlah fasilitas kesehatan yang cukup dan dari kelompok 3 dapat dikatakan memiliki jumlah fasilitas kesehatan yang kurang. Pengelompokan tersebut didasarkan pada jarak terdekat dari masing- 
masing kota dan jenis persepsi pada tiap kelompok didasarkan pada letak kuadran masingmasing kelompok.

\subsection{Menghitung Nilai Stress}

Menghitung nilai stress dapat dilakukan dengan menggunakan persamaan (4) diatas, sehingga didapat nilai stress hasil iterasi dengan menggunakan software SPSS sebagai berikut:

\begin{tabular}{l} 
Iteration history for the 2 dimensional solution (in squared distances) \\
Young's S-stress formula 1 is used. \\
Iteration S-stress Improvement \\
$1 \quad, 00172$ \\
Iterations stopped because \\
S-stress is less than ,005000 \\
For matrix \\
Stress $=, 01069 \quad \mathrm{RSQ}=, 99978$ \\
\hline
\end{tabular}

Dari hasil output di atas di dapat nilai stress adalah sebesar 0,01069 atau 1,06\% berdasarkan garis pedoman kriteria masuk ke dalam sempurna. Nilai RSQ mengindikasikan proporsi varians data input dapat dijelaskan oleh model multidimensional scaling. Menurut Maholtra (1999), model dapat diterima jika $\mathrm{RSQ}>=0,6$, berdasarkan output SPSS di atas nilai RSQ sebesar 0,99978>0,6 artinya bahwa model dapat diterima untuk mengambarkan pemetaan 9 Kota di Jawa Barat berdasarkan jumlah sarana kesehatan yang ada pada kotakota teresebut yaitu Rumah Sakit Umum (RSU), Rumah Sakit Ibu Anak/Bersalin (RSA), Puskesmas, Posyandu, Balai Pengobatan dan Apotek pada tahun 2013.

\section{Simpulan}

Dari hasil pemetaan diatas, tiga kelompok kota yang memiliki kemiripan antar anggotanya namun berbeda dengan kelompok lainnya. Ketiga kelompok tersebut adalah kelompok 1 yaitu Kota Banjar, Kota Sukabumi, Kota Tasikmalaya, Kota Cirebon, dan Kota Cimahi, untuk kelompok 2 yaitu Kota Bandung dan kelompok 3 yaitu Kota Bekasi, Kota Bogor, dan Kota Depok. Tiap kelompok yang terbentuk memiliki kemiripan karakteristik dari jumlah fasilitas sarana kesehatan.

Dapat disimpulkan bahwa pada kelompok satu memiliki jumlah fasilitas kesehatan yang baik, sedangkan dari kelompok 2 dapat dikatakan memiliki jumlah fasilitas kesehatan yang cukup dan dari kelompok 3 dapat dikatakan memiliki jumlah fasilitas kesehatan yang kurang. Pengelompokan tersebut didasarkan pada jarak terdekat dari masing-masing kota dan jenis persepsi pada tiap kelompok didasarkan pada letak kuadran masing-masing kelompok. Hasil penelitian ini dapat menjadi bahan pertimbangan bagi pemerintah kota untuk menambahkan fasilitas kesehatan pada kota tersebut.

\section{Daftar Pustaka}

1. A, Walundungo G, dkk. 2014. Penggunaan Analisis Multidimensional Scaling Untuk Mengetahui Kemiripan Rumah Makan di Manado Town Square Berdasarkan Karakteristik Pelanggan. JdC, Vol. 3, No. 1, Maret 2014. FMIPA UNSRAT. 
2. Ginanjar, I. 2008. Aplikasi Multidimensional Scaling Untuk Memposisikan Produk Pada Masalah Product Existing. Staf Pengajar Jurusan Statistika FMIPA UNPAD, Bandung.

3. Hair, J.F. Jr., Anderson, R.E., Tatham, R.L. danBlack, W.C.,1998), Multivariate Data Analysis, (5th Edition),. Prentice Hall, New Jersey.

4. Johnson, R.A.; Wichern, D. W., 1992. Applied Multivariate Statistical Analysis, PrenticeHall Inc, New Jersey.

5. Maholtra, DF. 1999. Marketing Research An Applied Orientation, $3^{\text {th }}$ Ed. Prentice-Hall Inc, New Jersey. 